\title{
Business Model of Learning Platforms in Sharing Economy
}

\author{
Eduardo Cornejo-Velazquez ${ }^{1}$, Mireya Clavel-Maqueda ${ }^{2}$, Hector Perez-Lopez-Portillo ${ }^{3}$ and \\ Ekaterina Lyubimova ${ }^{4}$ \\ ${ }^{1}$ Autonomous University of the State of Hidalgo, Hidalgo, México \\ ${ }^{2}$ Popular Autonomous University of the State of Puebla, Puebla, Mexico \\ ${ }^{3}$ University of Guanajuato, Guanajuato, México \\ ${ }^{4}$ University 2035, Moscow, Russia \\ ecornejo@uaeh.edu.mx \\ mireva.clavel@upaep.edu.mx \\ hplp@ugto.mx \\ katerina.lyubimova@gmail.com \\ DOI: 10.34190/EJEL.20.18.1.008
}

\begin{abstract}
Current economy is driven by innovation and knowledge. Sharing economy is a new perspective on economics that impulses a new economy based on trust. In this article, the key components of global education business, based on the analysis of different types of business cases such as edX, Coursera, Udacity, Udemy, and Codecademy are established. For this research we carried out a systematic literature review based on different cases to highlight some of the main advantages of the models of global education services based on sharing economy, as a result, we found out that the main components of the learning platform business model in sharing economy are related to the online cash concept, shared resources, shared knowledge access, networking collaboration, analysis based on big data, joint consumption, rather than ownership while the government loses monopolies of knowledge. Our claim is that global education will be supported by a collaborative consumption model based on the online cash concept, shared resources, and shared knowledge access.
\end{abstract}

Keywords: MOOC platforms, business model innovation, share economy, open education, Business Model Canvas.

\section{Introduction}

The Cambridge English Dictionary defines 'sharing economy' as an economic system based on people sharing possessions and services, either for free or for payment, usually organized and mediated through the internet. Sharing economy is a perspective that drives a new economy based on trust, as part of a culture of sharing, rather than ownership (Aigrain, 2012; Ert, Fleischer and Magen, 2016). The concepts of 'sharing' and 'economy' have become increasingly co-joined to describe emergent means of enjoying, acquiring or exchanging goods, services, knowledge, and experiences together with others, often mediated with digital technologies. Indeed, some consultants and practitioners suggest this new model of Information and Communications Technology (ICT) mediated sharing represents a 'third great economic revolution' (Munger, 2016).

In addition, the technological innovations and connectivity expansion have led to a multi-directional development of new companies and business activities that have often over-flown into more traditional sectors and, therefore, those sectors have been redefined. Given the previous scenario, it is relevant to know how the change in global education is taking place, not only within the market, but within the global society (Brugnoni, Polzonetti and Sagratella, 2016).

Because of that, many believe that the sharing economy is an appealing alternative for consumers due to its economic benefits (i.e. low cost, new income opportunities), which have been considered important after the global economic trends (Hansen-Henten and Maria-Windekilde, 2016; Breidbach and Brodie, 2017; Wallenstein and Shelat, 2017b). The sharing economy has been presented as a new opportunity for doing business and for nurture new consumption attitudes (Wallenstein and Shelat, 2017a).

Therefore, participation in sharing economy is motivated by many factors such as sustainability, enjoyment of the activity as well as economic gains, also an attitude-behavior gap might exist; people perceive the activity positively and say good things about it, but this good attitude does not necessary translate into action (Hamari, Sjöklint and Ukkonen, 2016). 
For this reason, the sharing economy can be defined as a socio-economic ecosystem that commonly uses information technologies to connect different stakeholders-individuals, companies, governments, and other, in order to make value by sharing their excess capacities for products and services (Hamari, Sjöklint and Ukkonen, 2016).

Additionally, sharing economy is gaining interest both in the management practice and academic sector alike. The main idea behind this phenomenon is that sharing products is more efficient than owning them individually (Eckhardt and Bardi, 2015). The most frequent reasons for joining sharing economy are 'for learning' and 'to share knowledge and skills'; practitioners improve their own knowledge through teaching and overcome the sacrifices to share with others (Sützl, 2012). By the end of 2018, learning platforms crossed 101 million learners, over 900 universities around the world had announced or launched 11,400 courses (Shah, 2019).

As we mentioned before, sharing economy seems to be recognized for increase assets utilization rather than ownership (Stephany, 2015); sharing economy implies a new culture of sharing goods and services (Davies et al., 2017). In case of learning platforms one important topic is defining the business model to participate in sharing economy market and which innovation strategies are used to generate competitive advantages.

In economic terms, the report from Global Market Insights, Inc. indicate that by 2025 the global online education market size is set to be over USD $\$ 300$ billion (Bhutani and Bhardwaj, 2019). This projection is based on market growth in the coming years, due to increased demand for training and cost-effective learning techniques in the business and academic sectors.

In this context, a business model is a system of components (customer value, scope, pricing, revenue sources, connected activities, implementation, capabilities and sustainability) and relationships between these components (Afuah and Tucci, 2003). Furthermore, Methlie and Pedersen (2007) have defined a business model that consists of three dimensions:

1. Service Strategy which includes service value proposition, and market focus;

2. Governance Form which refers to the ways in which flows of information, resources and goods are controlled by the parties of the value-creating business network;

3. Revenue Model which includes revenue valuation and sharing.

The assertion is that a business model innovation involves not only an increase in customer benefit over the existing alternatives, but that organizational processes are designed or reengineered in order to deliver this benefit (Robertson, 2017). Then, a considerable proposition of business model innovation today is tied to the role of the Internet and connected technologies (lansiti and Lakhani, 2014; Porter and Heppelmann, 2014) but this doesn't necessarily represent the basis of business model innovation.

Likewise, education, training, and lifelong learning are critical to global society in order to advance as knowledge-based economies. Education systems worldwide are undergoing major upheavals and transformations; therefore, today more than ever, a new paradigm for this sector is necessary (Development Bank, 2014). Technological innovations also offer the solutions to drastically reduce the costs of educational resources, thanks to the implementation of new usage methods and new organizational models for the learning platforms (Brugnoni, Polzonetti and Sagratella, 2016).

Additionally, if knowledge is the key driver of modern economy, it is important to analyze how global education can be supported by a collaborative consumption model based on an online learning concept, shared resources and shared knowledge access (Cooke, 2001).

On the other hand, a business model that captures the key aspects of the company's business should address four questions: what value propositions are being offered? who are the customers? how do operations have to work? and why is the business model financially interesting? (Blaschke et al., 2017).

Consequently, this research analyses the innovation business models in learning platforms operating within a sharing economy, to identify the key components of global education business. In order to do this, we assumed that learning platforms in sharing economy involve educational technologies, content and service provider, and academic, corporate and government end-use that cooperate, collaborate and interact to 
create, deliver and receive value. Thus, in this context, we have established two research question research questions (RQ):

RQ1: What are the main components of the business model of learning platforms in the sharing economy? RQ2: What are the components of the business model that make learning platforms different?

To achieve this, we studied different models that involve the global education market as part of the sharing economy model, conducting afterwards a systematic literature reviews to determine the components and their relationships and differences that can help us to solve our research questions.

\section{Research methods and sample selection}

One of our goals was to address the analysis of innovation in business models related to sharing economy and to identify the key components of global education business. We used Okoli's methodology to guide the process of the literature review (Okoli, 2015).

Our first step was to design a research protocol, adapted to match our expected research outcomes. Secondly, we searched scientific databases Ebsco, Scopus - ScienceDirect and Google Scholar using the keywords 'business model' AND 'sharing economy' during the 2013-2018 period. During this stage, we collected a group of 48,627 scientific publications; 42 of Ebsco, 41,105 of Scopus - ScienceDirect and 7,480 of Google Scholar.

Then, we filtered the results with the keywords "learning" OR "education" OR 'online course' to select our collection of main studies related to our research questions. Our final group had 92 scientific publications; 14 in Science Direct and 78 for Google Scholar.

As a result of the literature review, the main research areas were identified that were related to learning platforms for higher education as an opportunity for participate in global education services (van Dijck and Poell, 2015; Kopnina, 2017; Escribano, 2018):

- Comparison of platforms learning in service and result terms to identification good practices and innovative strategies (Siedel, 2016; Robertson, 2019).

- Proposal conceptual frameworks for the construction of new courses as guide to new projects (Kjaer, 2014; Nguyen, 2017).

- Deploy technological innovations in platform infrastructure and end-use level to build competitive advantages (Worth, 2017; Zhang, 2017; Duy et al., 2018). Studies to determine the satisfaction of practitioners, teachers/instructors and learners (Worth, 2015).

For the analysis of the business models implemented by the learning platforms, articles with topics directly related to the research questions were included. We used the method of analysis of thematic content to grouped into categories to obtain information of business models in share economy (Stephany, 2015; Blaschke et al., 2017; Robertson, 2017; Sieber and Seager, 2017), main components in business model (Long, 2017; Voigt, Buliga and Michl, 2017) and learning platforms in share economy (Burd, Smith and Reisman, 2015; Daniel, Vázquez Cano and Gisbert, 2015; Epelboin, 2017).

After selecting the collection of studies, we decided to use the Osterwalder's (2004) Business Model Canvas (BMC) to compare and define the study cases business models. BMC merging key elements in a single strategic field makes it possible to study in details enterprise's work and to analyze the flows of income, expenditure and profit influenced by the most important external factors which mediate internal environment changes (Dudin et al., 2015). And, BMC is an excellent unit of analysis for studying and advancing common managerial and entrepreneurial approaches in business (Schaltegger, Hansen and Lüdeke-Freund, 2016). It helps to make sense of "doing business" (Trimi and Berbegal-Mirabent, 2012; Blank, 2013; Massa L. and Tucci C., 2013). The BMC contains nine structured elements of knowledge that represent the content ("what") of doing business (Keane, Cormican and Sheahan, 2018). The dimensionality of the BMC is a key issue for both entrepreneurship and management research on the business model (Amit and Zott, 2001; Magretta, 2002; Morris, Schindehutte and Allen, 2005; Tikkanen et al., 2005).

A multiple and descriptive case study has been used as the main research method; and to select the case study, we created a list of learning platforms based on literature review, adding some information of the global 
Amazon Alexa Ranking (Jayasekara, 2017). The criteria were to exclude platforms of our group that were not available in English, 'aggregators' -function as a search engine and redirect to another platform-, open hosting sites, exclusively for corporate training and online extension of a single University.

Finally, we considered the number of learners reported in the stats of Digital Marketing Ramblings (Smith, 2019) for the learning platforms and choose the main platforms for this study. A brief description of these five platforms including Udemy, Coursera, edX, Codecademy and Udacity, is shown in Table 1.

Table 1: Description of learning platform cases.

\begin{tabular}{|l|l|l|l|l}
\hline \multicolumn{1}{|c|}{ Name } & \multicolumn{1}{c|}{ Description } & \multicolumn{1}{c|}{ Founded } & Vocation & Learners \\
\hline Udemy & $\begin{array}{l}\text { An open marketplace through which } \\
\text { anyone can create and tak courses. It } \\
\text { offers a large variety of topics from } \\
\text { technology skills to entertainment }\end{array}$ & $\begin{array}{l}\text { February 2010 by Eren } \\
\text { Bali, Oktay Caglar, } \\
\text { Gagan Biyani }\end{array}$ & For profit & 30 million \\
\hline Coursera & $\begin{array}{l}\text { A platform that offers university-style } \\
\text { courses provided by universities or or } \\
\text { organizations world-wise }\end{array}$ & $\begin{array}{l}\text { April 2012 by Daphne } \\
\text { Koller, Adrew Ng }\end{array}$ & For profit & 40 million \\
\hline edX & $\begin{array}{l}\text { A platform that offers university-style } \\
\text { courses and provides traditional } \\
\text { instruction education }\end{array}$ & $\begin{array}{l}\text { May 2012 by Anant } \\
\text { Agarwal, Chris Terman, } \\
\text { Piotr Mitros }\end{array}$ & Non profit & 18 million \\
\hline Codecademy & $\begin{array}{l}\text { An educational company that teaches } \\
\text { coding in different programming } \\
\text { languages }\end{array}$ & $\begin{array}{l}\text { August 2011 by Zach } \\
\text { Sims, Ryan Bubinski }\end{array}$ & Non profit & 45 million \\
\hline Udacity & $\begin{array}{l}\text { A platform that mainly provides courses } \\
\text { in the IT field to teach skills needed by } \\
\text { employees }\end{array}$ & $\begin{array}{l}\text { June 2011 by Sebastian } \\
\text { Thrun, David Stavens, } \\
\text { Mike Sokolsky }\end{array}$ & For profit & 8 million \\
\hline
\end{tabular}

Source: Authors(2019) with data in (Long, 2017), (Voigt, Buliga and Michl, 2017) and (Smith, 2019).

Google Trends has been used as an analytical tool to visualize audience interests in learning platforms. Researchers studied the traffic trend of five cases included in the search for the last five years (Figure 1), the $x$ axis corresponds to the analysis period while the $y$ axis corresponds to audience traffic, where a value of 100 indicates the maximum value while 0 the lowest. From 2013 to 2018, Coursera had the highest audience traffic although it had a downward trend by the end of the period, while edX, Codecademy and Udacity were in a similar range. For the 2017-2018 period, Udemy increased its audience traffic becoming the most popular, while Coursera remained in the same range as edX, the case of Udacity presents an upward trend and Codecademy has the least level.

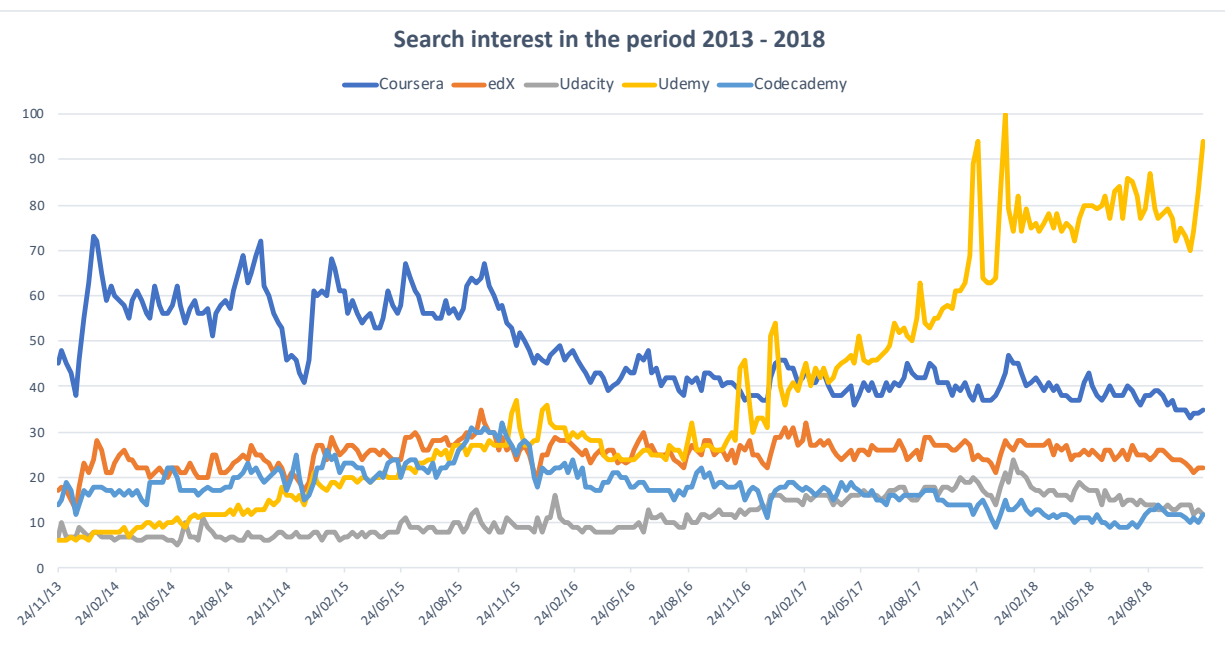

Figure 1: Audience traffic trend of the five sample websites.

Source: Google Trends (https://trends.google.com). 
So, in order to determine the market segment to which each platform is related, the type of courses offered was considered. Some platforms target a horizontal market by offering courses across a wide variety of topics, while others focus on a vertical market by offering courses in a specific field. Whereas some platforms are more academic-oriented, other ones are supported by industry, therefore they are not restricted to academic (Long, 2017).

To compare learning platforms' target markets, Table 2 classifies them into four blocks with two dimensions: horizontal versus vertical market, academic versus non-academic oriented.

Table 2: Market segment of learning platforms.

\begin{tabular}{|c|c|c}
\hline \multirow{2}{*}{ Market type } & \multicolumn{2}{|c}{ Market orientation } \\
\cline { 2 - 3 } & Academic-oriented & Non-academic oriented \\
\hline Vertical market & & Udacity, Codecademy \\
\hline Horizontal market & Coursera, edX & Udemy \\
\hline
\end{tabular}

Source: Authors(2019) with data in Long (Long, 2017).

As a result, Coursera, edX and Udemy target a horizontal market by offering courses across a large variety of topics, while Udacity and Codecademy focus on a vertical market by offering courses in a specific field. While Coursera and edX are academic-oriented; Udacity, Codecademy and Udemy are non-academic oriented and supported by industry.

Innovation business models in a sharing economy were analysed through the prism of Osterwalder's BMC to describe and evaluate the nine dimensions of a business model: customer segments, value proposition, customer channels, customer relationships, revenue streams, key resources, key activities, key partners, and cost structure.

Finally, we worked in pairs to construct the five BMC considering the theoretical concepts of the analysis of content of the scientific literature. We visited the websites of the learning platforms to collect data of interest. In addition, we registered as users of some courses offered to explore the contents, designs and interaction with the user to determine the components of the business model. Authors collaboratively defined the final version of each BMC.

\section{Business model of sample cases}

The following section analyses the components of the business model of five learning platforms after building a business model canvas for each one.

\subsection{Customer segment}

According to Osterwalder (2010), it is important for the company to define its focused market in order to study in depth the specific needs of the target sector.

Table 3: Customer segments of learning platforms.

\begin{tabular}{|l|c|c|c|c|c}
\hline \multirow{2}{*}{\multicolumn{1}{c|}{ Customer segments }} & \multicolumn{5}{c}{ Learning platform } \\
\cline { 2 - 6 } & edX & Coursera & Udacity & Udemy & Codecademy \\
\hline University students & $\mathrm{X}$ & $\mathrm{X}$ & $\mathrm{X}$ & $\mathrm{X}$ & $\mathrm{X}$ \\
\hline High school students & $\mathrm{X}$ & $\mathrm{X}$ & $\mathrm{X}$ & $\mathrm{X}$ & $\mathrm{X}$ \\
\hline Career changers & $\mathrm{X}$ & $\mathrm{X}$ & $\mathrm{X}$ & $\mathrm{X}$ & $\mathrm{X}$ \\
\hline Updated employees & $\mathrm{X}$ & $\mathrm{X}$ & $\mathrm{X}$ & $\mathrm{X}$ & $\mathrm{X}$ \\
\hline Partner universities & $\mathrm{X}$ & $\mathrm{X}$ & & & \\
\hline Companies & $\mathrm{X}$ & $\mathrm{X}$ & $\mathrm{X}$ & & \\
\hline Government and organizations & & $\mathrm{X}$ & & & \\
\hline Instructors & & & & $\mathrm{X}$ & $\mathrm{X}$ \\
\hline
\end{tabular}

Source: Authors (2019). 
Table 3 shows the different types of customer segments to verify differences or coincidences. All platforms are available to university and high school students to complement their official courses; to career changers offering the experience or skills to land a new job in their desired field; and to updated employees to catch up on their professional and personal skills. Only edX and Coursera work with partner universities to publish their online courses for their students and all other users of the platforms. On the other hand, edX, Coursera and Udacity serve companies with personalized programs to update specific skills of their employees. Coursera provides their courses to government and organizations to update their staff on specific topics.

\subsection{Value proposition}

The role of entrepreneurs is to build new value propositions within an organization, while the role of managerial services is to implement entrepreneurial ideas and proposals (Demil and Lecocq, 2010). Value proposition refers to the way in which organizations create value for their customers and for each party engaged in service provision (Gao and Zhang, 2016).

As a result of the literature review, we determined some usual value proposals, contrasting them afterwards to find the similarities and differences between learning platforms, as shown in Table 4.

All of them offer professional online education, normally well-structured, by using traditional instructional methods such as presentations, assignments, and tests with a convenient and rigorous learning style that allows users to adjust their education according to their needs. Additionally, some of them focus on value proposition offering additional benefits such as quality courses, easy to access tools, great scale and economy.

Table 4: Value proposition of learning platforms.

\begin{tabular}{|l|c|c|c|c|c}
\hline \multirow{2}{*}{\multicolumn{1}{c|}{ Value proposition }} & \multicolumn{5}{c}{ Learning platform } \\
\cline { 2 - 6 } & edX & Coursera & Udacity & Udemy & Codecademy \\
\hline Professional online education & $\mathrm{X}$ & $\mathrm{X}$ & $\mathrm{X}$ & $\mathrm{X}$ & $\mathrm{X}$ \\
\hline Online university & $\mathrm{X}$ & $\mathrm{X}$ & & & \\
\hline Quality, access, scale and economic & $\mathrm{X}$ & $\mathrm{X}$ & $\mathrm{X}$ & $\mathrm{X}$ & $\mathrm{X}$ \\
\hline Job ready skills & & & $\mathrm{X}$ & $\mathrm{X}$ & $\mathrm{X}$ \\
\hline Education in IT field only & & & $\mathrm{X}$ & & $\mathrm{X}$ \\
\hline Upgrade for employment & & & $\mathrm{X}$ & $\mathrm{X}$ & \\
\hline Global marketplace & & & & $\mathrm{X}$ & \\
\hline Blended learning & $\mathrm{X}$ & $\mathrm{X}$ & & & \\
\hline
\end{tabular}

Source: Authors (2019).

Coursera and edX offer online university courses and blended learning to combine academic oriented elearning with face-to-face classes for enrolled students. Udacity, Udemy and Codecademy offer job skills education for those who need to obtain new opportunities in their work field, while Udacity and Udemy provide opportunities to upgrade employment skills. Udacity and Codecademy only offer IT education. Udemy was the most outstanding due to a wider variety of distinctive characteristics, besides, it is the only one that incorporates a global marketplace where students can build and sell their own courses and generate profits for themselves.

\subsection{Channels}

The channel describes how a company communicates with its customer segments reaching them to deliver its value proposition. All the cases analysed use their own web platform as a communication channel with their client segment using it to deliver the value proposal, as well as to create a link with them to facilitate their contents and materials per every course offered. All platforms use mobile applications to provide to their users the ability to access them from their mobile devices. Regarding this field, there are not any distinctive features, all platforms provide their services through the same channels.

\subsection{Customer relationships}

This area describes the types of relationships established by a company with specific customer segments. Table 5 describes the types of relationships established by every learning platform researched. 
Table 5: Customer relationships of learning platforms.

\begin{tabular}{|l|c|c|c|c|c}
\hline \multirow{2}{*}{\multicolumn{1}{c|}{ Customer relationships }} & \multicolumn{5}{c}{ Learning platform } \\
\cline { 2 - 6 } & edX & Coursera & Udacity & Udemy & Codecademy \\
\hline Self service via online platform & $\mathrm{X}$ & $\mathrm{X}$ & $\mathrm{X}$ & $\mathrm{X}$ & $\mathrm{X}$ \\
\hline Community approach & $\mathrm{X}$ & $\mathrm{X}$ & $\mathrm{X}$ & $\mathrm{X}$ & $\mathrm{X}$ \\
\hline Face-to-face interaction & $\mathrm{X}$ & $\mathrm{X}$ & $\mathrm{X}$ & & \\
\hline Affiliation models & $\mathrm{X}$ & $\mathrm{X}$ & & & \\
\hline Personalized support & & & $\mathrm{X}$ & & \\
\hline Mentorship & & & $\mathrm{X}$ & & \\
\hline
\end{tabular}

Source: Authors (2019).

Self service via an online platform that helps them to deliver their services to all users and the configuration of user groups through community outreach were common elements in all cases, both options are focused on the acquisition and retention of users. Coursera, edX and Udacity offer face-to-face interaction between users as well as personal interaction to answer their questions, relieve their anxiety or share their experiences; subsequently, the affiliation models of edX and Coursera allows some rewards to be awarded to learners to turn a short-term relationship into a long-term one. Only Udacity includes personalized support and mentorship to provide personal help to customers in order to solve their problems.

\subsection{Revenue streams}

The revenue models of learning platforms are still under development and new models are emerging every day. According to Long (Long, 2017) revenue streams are related to sales of courses or other products; services to provide a platform for organizations so their employees are able to take their own training programs; advertising fees directly or indirectly related to trademarks, brands or products involved in courses or final projects; enrollment fee to take unlimited courses for a period of time; and special programs, for example holding events and contests, or sharing students' data with potential employers. Researchers coded the revenue sources for the five cases and then classified the sources into eight major categories, as shown in Table 6.

Table 6: Revenue streams of learning platforms.

\begin{tabular}{|l|c|c|c|c|c|}
\hline \multirow{2}{*}{\multicolumn{1}{|c|}{ Revenue streams }} & \multicolumn{5}{c|}{ Learning platform } \\
\cline { 2 - 6 } & edX & Coursera & Udacity & Udemy & Codecademy \\
\hline Course Sponsorship & $\mathrm{X}$ & $\mathrm{X}$ & & & \\
\hline Donation & $\mathrm{X}$ & & & & $\mathrm{X}$ \\
\hline Employee Training & & $\mathrm{X}$ & $\mathrm{X}$ & $\mathrm{X}$ & $\mathrm{X}$ \\
\hline Platform usage/service fee & $\mathrm{X}$ & & & & $\mathrm{X}$ \\
\hline Recruiting Program & & $\mathrm{X}$ & $\mathrm{X}$ & & $\mathrm{X}$ \\
\hline Specializations & $\mathrm{X}$ & $\mathrm{X}$ & $\mathrm{X}$ & & \\
\hline Tuition Fees & & $\mathrm{X}$ & & $\mathrm{X}$ & $\mathrm{X}$ \\
\hline Verified Certificate & $\mathrm{X}$ & $\mathrm{X}$ & & & \\
\hline Degrees & $\mathrm{X}$ & $\mathrm{X}$ & $\mathrm{X}$ & $\mathrm{X}$ & \\
\hline
\end{tabular}

Source: Authors (2019).

As it can be seen, Coursera, Udacity, Udemy and Codecademy sell employee training to companies and organizations. Coursera, Udacity and Codecademy generate profits through the recruiting program sharing students' data with those who are looking for candidates for vacant positions. Udemy, Coursera and Codecademy charge students a small fee to take certain courses. Coursera, edX and Udacity develop specializations combining relevant courses and the capstone project in a package to sell it to students.

Udemy, Udacity, Coursera, and edX offer degrees to certify the knowledge acquired, students pass and pay for a group of courses configured to support the degree. Coursera and edX use course sponsorship charging companies and organizations to mention their brand or products in classes or use their banners to advertise them in videos. Codecademy and edX receive donations from companies, organizations and foundations. Likewise, both platforms have a purchase fee to use, support and service the platform when companies and 
organizations offer their own courses. Finally, for the cases of edX and Coursera, once students have finished a class that is normally free, they can decide if they want a certificate by paying a small fee.

\subsection{Key activities}

Key activities are the activities that learning platforms need to do in order to deliver their value proposition to customers. Researchers coded the key activities for the five cases and then classified the sources into seven major categories, Table 7.

Table 7: Key activities of learning platforms.

\begin{tabular}{|l|c|c|c|c|c|}
\hline \multirow{2}{*}{\multicolumn{1}{|c|}{ Revenue streams }} & \multicolumn{5}{c|}{ Learning platform } \\
\cline { 2 - 6 } & edX & Coursera & Udacity & Udemy & Codecademy \\
\hline Financial sustainability & $\mathrm{X}$ & $\mathrm{X}$ & $\mathrm{X}$ & $\mathrm{X}$ & $\mathrm{X}$ \\
\hline Continuous improvement & $\mathrm{X}$ & $\mathrm{X}$ & $\mathrm{X}$ & $\mathrm{X}$ & $\mathrm{X}$ \\
\hline Converting course & $\mathrm{X}$ & & & & \\
\hline Partner acquisition & $\mathrm{X}$ & $\mathrm{X}$ & & & \\
\hline Increasing courses & & $\mathrm{X}$ & & $\mathrm{X}$ & $\mathrm{X}$ \\
\hline Updating courses & & & $\mathrm{X}$ & & \\
\hline Personal code review & & & $\mathrm{X}$ & & \\
\hline
\end{tabular}

Source: Authors (2019).

Financial sustainability to operate and obtain more users and the continuous improvement in all process were common key activities of all learning platforms. Increasing the number of courses is relevant to Coursera, Udemy and Codecademy, because it gives them the possibility to rise the number of customers and obtain better revenues. EdX considers important to convert classroom training into online training to increase university courses availability.

Coursera and edX see partner acquisition as a key activity to build bridges with universities worldwide strengthening their offer of professional online education. In the case of Udacity, updating courses is important to keep their content relevant according to employment needs, on the other hand, the function of the personal code review is important as well in order to provide this service to customers helping them to answer doubts and solve problems.

\subsection{Key resources}

Key resources describe the most important assets required to build your business. There are irreplaceable elements for the value proposition of learning platforms. Throughout the analysis, researchers identified four key resources for all study cases: platform design, instructional design, expert knowledge, and brand recognition.

Platform design is important because it is the main communication channel to bring value proposal to the desired customer segment. In this sense, the platform is configured to offer mobility and connectivity to consumers, it must be available to all devices at every moment. Usability and user experience must be guaranteed by the front-end, while scalability and security are the responsibility of platform's back-end.

Instructional design has a crucial role in the systematic development of instructional specifications using learning and instructional theory to ensure the quality of instructions and creating learning experiences that learners can enjoy.

Expert knowledge is very important to ensure that courses offered are high quality and are constantly being updated in accordance with the value propositions of the learning platforms. Finally, brand recognition refers to the fact that a platform's name should be recognized, associating it to quality and professional education.

\subsection{Key partners}

Key partners are the relationships established with other businesses or non-consumer entities. They are critical, so the learning platform can implement its key activities. During the analysis, researchers identified two groups of key resources for all study cases: universities and instructors. 
Harvard University and Massachusetts Institute of Technology have created a partnership with edX to generate courses and share their brands. On the other side, Coursera is linked to the universities of Stanford, Princeton, Michigan and Pennsylvania with the same purpose. Udacity receives support from Stanford University, and universities from different parts of the world are key partners for edX and Coursera in order to expand its education offer to many countries.

The team of instructors is a vital partner for Udacity, Udemy and Codecademy, because they are in charge of designing, supporting and updating the courses offered to the customers.

\subsection{Cost structure}

Cost structure describes all the costs and expenses incurred by learning platforms: it not only indicates the total amount that they must spend, but also the format in which they are spent. The authors only have access to general fixed costs for the case studies.

For all cases, the cost of maintaining the platform is the main fixed cost that must be paid, including lodging, operation and maintenance. Regarding creation, updating and maintenance of the courses' content, there is a content creation cost. On the other hand, marketing promotion activities have an associated cost as well. Finally, the management of the platform has administrative costs that must be considered in the cost structure.

\section{Discussion}

As a result of the analysis of five global education businesses, we agree that the main principles of the business models of learning platform are shared resources, access to shared knowledge, networked collaboration, and joint work instead of ownership.

Learning platforms are still being developed and new business models are reconfigured every day. However, it is relevant for researchers and practitioners to analyze the main components of learning platforms' business models, in order to have a frame of reference for the services offered to the market.

Dimensionality of the BMC model allowed us to determine the characteristics of each case studied based on the examination of nine components that define its business model. This way it was possible to compare the components of the business model between the different cases studied.

In all the analysed cases, we defined the main components of the business models: customer segment, value proposition, communication channels, customer relationships, revenue streams, key activities, key resources, key partners, and cost structure.

Business models of learning platforms have four similar components that not allow to offer significant differences: communication channels, key resource, key partners, and cost structure.

In the case of communication channels, all of them use their own web platform and mobile applications to provide their users access to the courses offered, as well as to create a link. Key resources for all study cases are platform design, instructional design, expert knowledge, and brand recognition. We identified two groups of key partners: universities and instructors; they are non-consumer entities and critical to implement learning platforms. Cost structure include platform maintenance; courses creation, updating and maintenance; marketing and advertising; and administrative activities.

In other hand, business models of learning platforms have five components that they use to build their competitive advantage: customer segment, value proposition, customer relationships, revenue streams, and key activities.

Learning platforms have their own customer segment that defines its target sector and focused market. We found similarities and differences in the way each platform creates value for their customers and for each party engaged in service provision. Every platform establishes different types of relationships with their specific customer segments. Revenue streams are still under development and new models are emerging, every case studied has different revenue sources regarding the market segment and types of courses offered. 
Key activities that the learning platform needs to do in order to deliver its value proposition to customers are important to compete by being different and attract more learners.

The main innovations for business models of learning platforms relate to value propositions, customer relationships, revenues streams, and key activities. For these business model components, the platform can design and deploy innovative strategies in terms of technology, service and content provider or focused enduser to build competitive advantages and differentiate from others.

In the university sphere, sharing economy offers the following key features: inclusion of non-academic sectors in learning platforms through a particular value proposition for a specific customer sector; professors share their knowledge and time in the open market and students easily access it.

The approach of learning platforms poses a challenge for college education that needs to change quickly. The cases studied allow us to consider an immediate alternative: to offer certain courses online which do not demand instruction and face-to-face discussion. And perhaps, this alternative represents lower costs for students and universities. Likewise, the use of learning platforms offers educational institutions the possibility to join forces to teach common courses. This will help them to optimize teaching resources, but they need to accept these credits.

\section{Conclusions, limitations and future directions}

This article explores the business models of learning platforms and determines the main components according to the BMC: customer segment, value proposition, communication channels, customer relationships, revenue streams, key activities, key resources, key partners, and cost structure.

As a result of the analysis, value proposition, customer relationships, revenues streams, and key activities can help to build a difference between learning platforms oriented to diverse customer segments, and they can focus on the selected market. In this case, the platform can decide what component will serve as basis of its competitive advantage.

Communication channels, key resources, key partners, and cost structure are very similar between platforms and do not allow to build a direct competitive advantage. One exception could be the quality and social recognition of key partners that can really make a difference between platforms.

The results of the research are limited to a sample of five cases, future research can expand sample size and explore the profitability model to combine the benefits of open education and higher education.

Two big trends dominated the learning platforms scene in 2018. First of all, paying customers (and revenues) are increasing. Secondly, more degrees are being offered through learning platforms. Both trends will allow us to explore new ways of revenue streams, instructional design innovation for new degrees, and technological innovations for communication channels and customer relationships; all of this focused on creating and defending competitive advantages.

\section{References}

Afuah, A. and Tucci, C. L., 2003. Internet business models and strategies : text and cases. New York: McGraw-Hill. Aigrain, P., 2012. Sharing: culture and the economy in the internet age, Vasa, p. 243.

Amit, R. and Zott, C., 2001. Value creation in E-business, Strategic Management Journal. 22(6-7), pp. 493-520. doi: 10.1002/smj.187.

Bhutani, A. and Bhardwaj, P., 2019. Global market insights. Available at:

https://www.gminsights.com/pressrelease/elearning-market (Accessed: 28 May 2019).

Blank, S., 2013. Why the lean start-up changes everything, Harvard Business Review, 91(5), pp. 63-72.

Blaschke, M. et al., 2017. Designing business models for the digital economy. In: G. Oswald, M. Kleinemeier eds. 2017. Shaping the digital enterprise. Cham: Springer pp. 121-136. doi: 10.1007/978-3-319-40967-2_6.

Breidbach, C. F. and Brodie, R. J., 2017. Engagement platforms in the sharing economy, Journal of Service Theory and Practice. 27(4), pp. 761-777. doi: 10.1108/JSTP-04-2016-0071.

Brugnoni, E., Polzonetti, A. and Sagratella, M., 2016. Innovation and governance: the role of sharing economy. In: F. Mata, A. Pont eds. ICT for Promoting Human Development and Protecting the Environment, vol 481, Cham; Springer pp. 195-204. doi: 10.1007/978-3-319-44447-5_18.

Burd, E. L., Smith, S. P. and Reisman, S., 2015. Exploring business models for MOOCs in higher education, Innovative Higher Education. 40(1), pp. 37-49. doi: 10.1007/s10755-014-9297-0. 
Cooke, P., 2001. Regional innovation systems, clusters, and the knowledge economy, Industrial and Corporate Change., 10(4), pp. 945-974. doi: 10.1093/icc/10.4.945.

Daniel, S. J., Vázquez Cano, E. and Gisbert, M., 2015. The future of MOOCs: adaptive learning or business model?', RUSC. Universities and Knowledge Society Journal. 12(1), p. 64. doi: 10.7238/rusc.v12i1.2475.

Davies, A. R. et al., 2017. OUP accepted manuscript', Cambridge Journal Of Regions, Economy And Society. 10(2), pp. 209230. doi: $10.1093 /$ cjres/rsx005.

Demil, B. and Lecocq, X., 2010. Business model evolution: in search of dynamic consistency, Long Range Planning. 43(2-3), pp. 227-246. doi: 10.1016/J.LRP.2010.02.004.

Development Bank, A., 2014. Innovative Asia: advancing the knowledge-based economy. Available at: https://www.adb.org/sites/default/files/publication/41752/innovative-asia-knowledge-based-economy.pdf (Accessed: 28 May 2019).

van Dijck, J. and Poell, T., 2015. Higher education in a networked world: european responses to U.S. MOOCs. Available at: https://papers.ssrn.com/sol3/papers.cfm?abstract_id=2645629 (Accessed: 29 May 2019).

Dudin, M. N., Kutsuri , G.N., Federova, I J., Dzusova, S. S. and Namitulina , A. Z. ., 2015. The innovative business model canvas in the system of effective budgeting, Asian Social Science. 11(7), pp. 290-296. doi: 10.5539/ass.v11n7p290.

Duy, P. T., Hien, D.T.T., Hien, D. H. and Pham, V.H, 2018. A survey on opportunities and challenges of Blockchain technology adoption for revolutionary innovation, in Proceedings of the Ninth International Symposium on Information and Communication Technology - SoICT 2018. New York, New York, USA: ACM Press, pp. 200-207. doi: 10.1145/3287921.3287978.

Eckhardt, G. and Bardi, F., 2015. The sharing economy isn't about sharing at all, Harvard Business Review, 28(1), pp. 881898.

Epelboin, Y., 2017. MOOCs: a viable business model?. In: Jemni M.Kinshik and Khribi, M. K. Open Education: from OERs to MOOCs. Cham: Springer, pp. 241-259. doi: 10.1007/978-3-662-52925-6_13.

Ert, E., Fleischer, A. and Magen, N., 2016. Trust and reputation in the sharing economy: The role of personal photos in Airbnb, Tourism Management. 55, pp. 62-73. doi: 10.1016/J.TOURMAN.2016.01.013.

Escribano, E., 2018. A preliminary assessment of the EU proposal on significant digital presence: a brave attempt that requires and deserves further analysis. In: Almudí Cid, J. M. Combating tax avoidance in the EU: harmonization and cooperation in direct taxation. Wolters Kluwer pp. 559-599 doi: 10.2139/ssrn.3191787.

Gao, S. and Zhang, X., 2016. Understanding business models in the sharing economy in China: a case study. In: Dwivedi, Y.K et al.,. Social Media: The Good, the Bad, and the Ugly. vol. 9844 Cham: Springer, pp. 661-672. doi: 10.1007/978-3319-45234-0_59.

Hamari, J., Sjöklint, M. and Ukkonen, A., 2016. The sharing economy: why people participate in collaborative consumption, Journal of the Association for Information Science and Technology. 67(9), pp. 2047-2059. doi: 10.1002/asi.23552.

Hansen-Henten, A. and Maria-Windekilde, I., 2016. Transaction costs and the sharing economy, Info. 18(1), pp. 1-15. doi: 10.1108/info-09-2015-0044.

lansiti, M. and Lakhani, K. R., 2014. Digital ubiquity: how connections, sensors, and data are revolutionizing business. Harvard Business Review. 92(1), pp. 90-99.

Keane, S. F., Cormican, K. T. and Sheahan, J. N., 2018. Comparing how entrepreneurs and managers represent the elements of the business model canvas, Journal of Business Venturing Insights. 9, pp. 65-74. doi: 10.1016/J.JBVI.2018.02.004.

Kjaer, A., 2014. The trend management toolkit: a practical guide to the future. London: Palgrave Macmillan, .

Kopnina, H., 2017. Teaching circular economy: overcoming the challenge of green-washing, Handbook of Engaged Sustainability, pp. 1-25. doi: 10.1007/978-3-319-53121-2_48-1.

Long, Y., 2017. Explore the business model of MOOCs.,In: International Conference on $\mathrm{HCl}$ in Business, Government, and Organizations. Cham: Springer, pp. 181-193. doi: 10.1007/978-3-319-58481-2_15.

Magretta, J., 2002. Why business models matter. Harvard Business Review, 80(5), pp. 86-92.

Massa L. and Tucci C., 2013. Business model innovation. In: Dodgson M., David M., and GannNelson P., The Oxford Handbook of Innovation Management, p. 752.Oxford: Oxford OUP,

Methlie, L. B. and Pedersen, P. E., 2007. Business model choices for value creation of mobile services, info. 9(5), pp. $70-85$. doi: $10.1108 / 14636690710816462$.

Morris, M., Schindehutte, M. and Allen, J., 2005. The entrepreneur's business model: toward a unified perspective, Journal of Business Research. 58(6), pp. 726-735. doi: 10.1016/J.JBUSRES.2003.11.001.

Munger, M. C., 2016. Tomorrow 3.0. The sharing economy, The Independent Review, 20(3), pp. 391-395.

Nguyen, T. M. L., 2017. Strategic marketing in education and training industry. Degree. Laurea University of Applied Sciences.

Okoli, C., 2015. A guide to conducting a standalone systematic literature review. Available at: https://hal.archivesouvertes.fr/hal-01574600/ (Accessed: 29 May 2019).

Osterwalder, A. et al., 2010. Business model generation : a handbook for visionaries, game changers, and challengers. Chichester John Wiley \& Sons

Osterwalder A., 2004. The business model ontology a proposition in a design science approach. Ph. D. Université de Lausanne.

Porter, M. E. and Heppelmann, J. E., 2014. Spotlight on managing the Internet Of Things how smart, connected products are transforming competition. Harvard Business Review, 92(11), pp. 65-88. 
Robertson, S. L., 2019. Comparing platforms and the new value economy in the academy. In: R. Gorur et al., eds.World yearbook of education 2019: comparative methodology in the era of big data and global networks. Ch. 10.

Robertson, T. S., 2017. Business model innovation: a marketing ecosystem view. AMS Review, 7(3-4), pp. 90-100. doi: 10.1007/s13162-017-0101-z.

Schaltegger, S., Hansen, E. G. and Lüdeke-Freund, F., 2016. Business models for sustainability: origins, present research, and future avenues, organization and environment pp. 3-10. .SAGE, Organization \& Environment, 29(1), doi: 10.1177/1086026615599806.

Shah, D., 2019. Year of MOOC-based Degrees: A Review of MOOC Stats and Trends in 2018 - Class Central. Available at: https://www.classcentral.com/report/moocs-stats-and-trends-2018/ (Accessed: 28 May 2019).

Sieber, S. and Seager, P. H., 2017. The digital economy: it's not the technology, it's the business model, stupid!, In: Rosenberg, M. and Seager, P., Managing Media Businesses. Palgrave Macmillan, pp. 135-157. doi: 10.1007/978-3319-52021-6_8.

Siedel, G. J., 2016. The three pillar model for business decisions: strategy, law and ethics. Van Rye Publishing, LLC.

Smith, C., 2019. Online company statistics and fun facts. Available at: https://expandedramblings.com/index.php/category/stats-2/technology-statistics/online-company-statistics/ (Accessed: 28 May 2019).

Stephany, A., 2015. The business of sharing: making it in the new sharing economy. Palgrave Macmillan. doi: 10.1057/9781137376183.

Sützl, W., 2012. Media, knowledge and education: cultures and ethics of sharing. Innsbruck University Press.

Tikkanen, H. et al., 2005. Managerial cognition, action and the business model of the firm, Management Decision. 43(6), pp. 789-809. doi: 10.1108/00251740510603565.

Trimi, S. and Berbegal-Mirabent, J., 2012. Business model innovation in entrepreneurship, International Entrepreneurship and Management Journal., 8(4), pp. 449-465. doi: 10.1007/s11365-012-0234-3.

Voigt, K.-I., Buliga, O. and Michl, K., 2017. Democracy in education: the case of edX. In: Business model pioneers. Management for professionals. Cham: Springer, pp. 159-170. doi: 10.1007/978-3-319-38845-8_13.

Wallenstein, J. and Shelat, U., 2017a. Hopping Aboard The Sharing Economy. Available at: http://imagesrc.bcg.com/Images/BCG-Hopping-Aboard-the-Sharing-Economy-Aug-2017_tcm30-168558.pdf (Accessed: 29 May 2019).

Wallenstein, J. and Shelat, U., 2017b. What's next for the sharing economy. Available at: http://imagesrc.bcg.com/Images/BCG-Whats-Next-for-the-Sharing-Economy-Oct-2017_tcm81-171872.pdf (Accessed: 29 May 2019).

Worth, J., 2015. The learning cliff: peer learning in a time of rapid change. In: Losh, E> MOOCs and their afterlives: experiments in scale and access in higher education,Ch. 6. doi: 10.7208/chicago/9780226469591.003.0007

Worth, J., 2017. Innovative pedagogies series: Synthesising approaches to openness. Available at: https://www.heacademy.ac.uk/system/files/jonathan_worth_final.pdf (Accessed: 29 May 2019).

Zhang, Y., 2017. Research on the flipped teaching mode of college english based on shared economic model and one belt and one road background, Boletín Técnico, 55(13). 